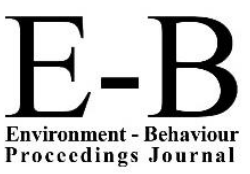

\title{
AicE-Bs2015Barcelona
}

$6^{\text {th }}$ Asia-Pacific International Conference on Environment-Behaviour Studies,

Barcelona School of Architecture (ETSAB), Barcelona, Spain,31 Aug.- 05 Sep. 2015

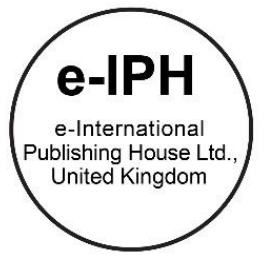

\section{Determinants of Food Heritage towards Food Identity}

\author{
Adilah Md Ramli *, Mohd Salehuddin Mohd Zahari, Mohd Zulhilmi Suhaimi, Salim Abdul Talib \\ Faculty of Hotel and Tourism Management, Universiti Teknologi MARA, Shah Alam 40450, Malaysia.
}

\begin{abstract}
Many studies on traditional food and food products towards identity have been carried out, but there is insufficient study relating to heritage context. In exploring this issue, conceptual frameworks have developed and examined the relationship between the determinants of food heritage and food identity. A total of 898 self-administered questionnaires were collected from the public in Klang Valley area, Malaysia and using statistical analysis using partial least square-structural equation modeling (PLS-SEM) from PLS 3 software to established the validity and reliability of the model as well as the relationship between the two factors. Results revealed that there are eight construct determinants of food heritage and one construct of food identity that represent the conceptual model, and there is a moderate relationship between the two variables.
\end{abstract}

(C) 2016. The Authors. Published for AMER ABRA by e-International Publishing House, Ltd., UK. Peer-review under responsibility of AMER (Association of Malaysian Environment-Behaviour Researchers), ABRA (Association of Behavioural Researchers on Asians) and cE-Bs (Centre for Environment-Behaviour Studies, Faculty of Architecture, Planning \& Surveying, Universiti Teknologi MARA, Malaysia.

Keywords: Determinants; food heritage; food identity; PLS-SEM

\section{Introduction}

Identity formation is a central issue in determining the image of a nation. Individuals, for example, are searching for who they are and what they want to be. This identity formation process continually occurs, and some are still puzzled or are still searching for their identity. Identity formations are even critical in multiracial and multicultural nations, and many countries are still struggling in developing their identity and social integration (Alba et al., 2000). These can be seen in a well-established nation such as America and European Nation (EU)(DeSoucey, 2010; Shane, 1994) as well as the country that had been influenced by colonization and migration such as Taiwan and Vietnam (Avieli, 2005; Hui-Tun, 2009, 2010).

In line with the above notion, questions arise as to why solid identity is needed;Vertovec (1999) posited that identity formation through integration among the different groups strengthens the structure of the society. Some argued that as society becomes more complex, assimilation and integration of the society will create a common perception of identity (Demo, 1992; Esser, 2003; Howard, 2000), while educational opportunities among different races, economy and social integration through the equal division of wealth can be a mechanism to create and strengthen the identity formation in a multicultural society (Bennett, 2001; Burgess, 2004). When come to the culture and identity of a nation, they are shaped and molded by the background of the people, their

* Corresponding author. Tel.: +60168317565 ; fax: +60332584868

E-mail address: $\mathbf{m} \_$adilah@hotmail.com

(C 2016. The Authors. Published for AMER ABRA by e-International Publishing House, Ltd., UK. Peer-review under responsibility of AMER (Association of Malaysian Environment-Behaviour Researchers), ABRA (Association of Behavioural Researchers on Asians) and cE-Bs (Centre for EnvironmentBehaviour Studies, Faculty of Architecture, Planning \& Surveying, Universiti Teknologi MARA, Malaysia. 
languages, and beliefs. When a nation is very sure of its identity, it tends to have a clear focus on what it wants in a positive manner (Ratnasingam, 2010).

Parallel with other nations, Malaysia is experiencing urgency in establishing its food identity when sharing food cultural background is becoming a central issue among the neighboring countries. Countries like Singapore and Indonesia, which share common historical roots and cultural heritage with Malaysia, are disputing over some of the traditional food (e.g rendang, nasi lemak, laksa, chilli crab, bak kut teh) when each country pursues to validate those traditional foods as their identity(Chong, 2012; Wo, 2009).Owing to this issue and according toChong (2009), each country is becoming more aggressive to defend and protect such heritage as theirs to safeguard the country's heritage as it is the core of the people's and country's identity. These incidences have opened the eyes of Malaysian on the importance to at least have our own cultures like oral tradition, languages, festive events, rites and beliefs, music and songs, the performing arts, traditional medicine, literature, traditional sports and games as well as traditional cuisine identity(Lim, 2012), although sharing the fundamental basis of it is unavoidable. Thus, this paper examines the conceptual frameworks of food heritage and food identity determinants and the relationship between the determinants.

\section{Literature Review}

\subsection{Food heritage an overview}

Heritage in the broad concept consists of tangible assets that include natural and cultural environments, landscapes, historic places, sites, built environments, and monuments, sites. Intangible assets, on the other hand, comprise of collections, the past, and continuing cultural practices as well as knowledge and life experiences (Farahani, Abooali, \& Mohamed, 2012; Halim \& Mat, 2010). UNESCO Convention 2003 and World Heritage Convention in 1994 perceived the tangible and intangible culture heritage from broader perspectives (Vecco, 2010). Tangible cultural heritage commonly relates to physical objects such as buildings, paintings, books, artefacts and monuments, while intangible cultural heritage refers to the non-material life objects such as language, music, dance, songs, religion, festivals and food besides also including traditions, practices and customs that become part of the culture that has been passed down from previous generations as part of their daily life practice (Md Nor et al., 2012; Shariff \& Zakaria, 2011).

In the context of food,A. Ramli and Zahari (2014) gave several interpretations on food heritage, such as in the association with the agriculture product; food originate from specific regional climate and lastly, food that have been produced using traditional methods of production. In the Malaysian context,Wahid, Mohamed, and Sirat (2009) associate food heritage with classical and traditional foods that are continuously practiced by all generations without major alteration of the original flavors. Food heritage can also be reflected from the environment history, belief, ideology and food technology of society in an era or period of time (Utusan, 2010). Meanwhile, Matta (2013); Ramli, Zahari, Halim, and Aris (2015); Ramli, Zahari, and Talib (2014) identified food heritage with traditional food, food passed down from one generation to another and food that relates to the cultural background that includes ethnic background and culture.

Former Heritage Commissioner of the National Heritage Department, Prof. Datuk Zuraina Majid defines food heritage based on two categories: synonymous or common foods which are part of our lives and foods that are almost extinct in other words it were once part of our culture but are slowly dying out (Wahid et al., 2009). The need for continuity and preserving food heritage is being considered as conditions of comparative advantage in maintaining local food culture in the face of external homogenizing pressures (Shariff, Mokhtar, \& Zakaria, 2008; UNESCO, 2008).

\subsection{The roles of National Heritage Department (NHD)}

National Heritage Department is a government department that handles maintaining, preserving and promoting the rich heritage of Malaysia. This department started as a division of Heritage under the Ministry of Culture, Arts and Heritage (KEKKWA)(Negara, 2015). In 2006, the Heritage Division, Ministry of Culture, Arts and Heritage joined Antiquities Division of the National Museum upgraded as the Department of National Heritage. The Department handles preserving and maintaining the National Heritage as enshrined in the National Heritage Act 2005 (Act 645)(Nor, 2006). From 2013 up to 2015, the National Heritage Department is under the Ministry of Tourism and Culture of Malaysia. The main functions of the National Heritage Department are: 1) to enforce the provisions under the National Heritage Act 2005; 2) to register the national heritage in the 
National Heritage List; 3) to maintaining and preserving the nation's heritage; 4) to conduct research and development related to heritage; 5) document and publish the results of research and reference materials related to heritage; 6) to plan, implement and coordinate activities related to heritage; 7) to assist in preparing World Heritage site nominations and the accolade of the world such as Memory of the World and Intangible Cultural Heritage; 8) Monitor World Heritage Site in Malaysia (Negara, 2015; Yusoff, Dollah, Kechot, \& Din, 2010).

\subsection{Determinant of food heritage}

Based on previous literature, food heritage determinants includes the historical elements, food characteristics, value of uniqueness, the practices and integration element (Belasco, 2008; Cleveland, Laroche, Pons, \& Kastoun, 2009; Guerrero et al., 2009; Hjalager \& Corigliano, 2000; Horng \& Tsai, 2010; Ishak, Zahari, Sharif, \& Muhammad, 2012; Kwik, 2008; Lin, Pearson, \& Cai, 2011; McDonald, 2011; Mohammad \& Chan, 2011; Phinney, 1990; Robinson \& Clifford, 2012; Rozin, 2006; Vanhonacker et al., 2010). Despite a continuously growing number of studies on food culinary tourism and food heritage, many links and dimension related to these themes are under-researched especially studies such as food heritage and food identity in the contemporary food and tourism literature.

The determinants have also adapted the nine criterias used in the Declaration of National Heritage, Act 645, the declaration of tangible or intangible heritage (e.g. food heritage) which must at least consist of:-

"67 (2)In making a declaration under subsection (1) the Minister may consider: (a) the historical importance, association with or relationship to Malaysian history; (b) the good design or aesthetic characteristics; (c)the scientific or technical innovations or achievements; (d) the social or cultural associations; (e) the potential to educate, illustrate or provide further scientific investigation in relation to Malaysian cultural heritage; $(f)$ the importance in exhibiting a richness, diversity or unusual integration of features; ( $g$ ) the rarity or uniqueness of the natural heritage, tangible or intangible cultural heritage or underwater cultural heritage; (h) the representative nature of a site or object as part of a class or type of a site or object; and (i) any other matter which is relevant to the determination of cultural heritage significance."(Malaysia, 2006).

Recognizing the historical elements, food characteristics, value of uniqueness, practices and integrations elements as food heritage attributes would help the nation in preserving and sustaining the ethnic foods potpourri for future generation, in the long run contributes toward nation food identity formation or nation food image not only among the Malaysian but also in the international arena. Preserving and creating nation food identity, on the other hand, catalyzing and fueling the patriotism and nationalism of the younger generation not only on food but others elements as well without tearing down each ethnic tradition identity.

\section{Research Design}

These studies examine the conceptual frameworks for the validity and reliability and the relationship between on the determinants of food heritage and food identity explore determinant of food heritage and food identity from the public point of view and the link of both factors. Specifically, it focuses on the respondents' demographic profiles. A quantitative method was used to gather all necessary information.

\subsection{Sample and procedure}

The information needed for this study gathered fromthe898 respondents in the Klang Valley (Lembah Klang) area using selfcompleted questionnaire survey. The target population was with Malaysian citizenship, consisting of major ethnic groups like Malay, Chinese and Indian. The reason for choosing the three major ethnic groups was due to the fact that their foods are commonly accepted among Malaysians, hence, classified as Malaysian foods and are qualified to be endorsed as heritage food (Bernama, 2012). In fact, some have been listed under the National Food Heritage (Negara, 2012). Owing to the widely distributed populations of Malay, Chinese and Indians, the researcher could not collect the desired information throughout the country.

Salkind (2003) argued that it would be practically impossible to collect data from every single element in the population, particularly when the investigation involves several hundred or even thousands of elements. Based on the popular argument, studying a sample rather than an entire population also leads to more reliable results, mainly because fatigue is reduced 
resulting in fewer errors in collecting data. The sample of population selected from the public who resided in Klang Valley, which comprises of the Federal Territory of Kuala Lumpur, Putrajaya, the Petaling district in Selangor (Shah Alam, Petaling Jaya and Subang Jaya), Gombak, Klang and Hulu Langat as well as their suburbs and adjoining cities and towns (Valley, 2014).

\subsection{Research instrument}

The self-administered questionnaire was developed and adapted based on several variables derived from the framework of the conceptual study. The items for the independent with dependent dimension and the type of scales that have been used are in the exploratory stage. Some of the items in each dimension of the determinants of food heritage (DFH) and food identity (FI) were adapted from previous similar studies (see Table 1).

In this study, purposive sampling was employed to select the elements from the sample. It is a form of convenience sampling in which the researcher's judgment is used to select the sample elements (Hair, Money, Samouel, \& Page, 2007). A preliminary screening process was carried out to select suitable respondents. The screening process based on the criteria set by the researcher, namely respondent should be $\geq 30$ years and knowledgeable about food heritage. Respondents who fulfilled the criteria could proceed with the questionnaire. Respondents were briefed on the aims of the study before the questionnaire was handed to them. Collected data were then analyzed using SPSS software version 20. Descriptive analysis (e.g. frequencies) has been used for respondents' demographic background.

To test the reliability of the model 65 items adapted from previous literature (Table 1) are modified accordingly to suit the $\mathrm{FH}$ context. Constructs were measured using a 5 -point Likert scale, using 5 for strongly agree and 1 for strongly disagree. Validation and reliability were analyzed using Smart PLS 3 software (Ringle, Wende, Sven, \& Becker, 2015). Structural Equation Modelling (SEM) was applied to test the relationships between the variables. SEM is a comprehensive statistical approach that allows for simultaneous evaluation and modification of a conceptual model. SEM is the only statistical method that allows all the relationships in a model to be tested completely and simultaneously. Testing and analyzing the relationships between the research models variables were achieved with smart partial least squares (PLS) software (Ringle et al., 2015) for a number of reasons such as PLS ability to handle both reflective and formative factors, which is widely recognized. It also offers minimal restriction on the distributional characteristics and sample size. Since this is an exploratory study, PLS is considered as a better method (Goh, 2015).

Table 1. Sources of measurement scale items

\begin{tabular}{|c|c|c|c|}
\hline Variable measurement & Source & $\begin{array}{l}\text { Number of } \\
\text { Items }\end{array}$ & $\begin{array}{l}\text { Type of } \\
\text { Variable }\end{array}$ \\
\hline Historical Value (HV) & $\begin{array}{l}\text { Guerrero et al. (2009); Horng \& Tsai (2010); Lin et } \\
\text { al (2011); McDonald (2011); Vanhonacker et al. } \\
\text { (2010) }\end{array}$ & 5 & Independent \\
\hline Traditional Originality (TvOr) & $\begin{array}{l}\text { Guerrero et al. (2009); Horng \& Tsai (2010); Lin et } \\
\text { al (2011); McDonald (2011); Vanhonacker et al. } \\
\text { (2010) }\end{array}$ & 10 & Independent \\
\hline Staple Ingredients (SI) & $\begin{array}{l}\text { Guerrero et al (2009); Horng \& Tsai (2010); Lin et } \\
\text { al (2011); Rozin (2006) }\end{array}$ & 5 & Independent \\
\hline Flavour Principle (FV) & Guerrero et al (2009); Lin et al (2011); Rozin (2006) & 5 & Independent \\
\hline Cooking Method (CM) & Lin et al (2011); Rozin (2006) & 5 & Independent \\
\hline Food Presentation (FP) & $\begin{array}{l}\text { Guerrero et al (2009); Horng \& Tsai (2010); Lin et } \\
\text { al (2011) }\end{array}$ & 5 & Independent \\
\hline $\begin{array}{l}\text { Variety and Commonality } \\
\text { (VcCc) }\end{array}$ & $\begin{array}{l}\text { Guerrero et al (20090; Cleveland et al. (2009); Kwik } \\
\text { (2008); Phinney (1990) }\end{array}$ & 10 & Independent \\
\hline $\begin{array}{l}\text { Process and Technology } \\
\text { (PT) }\end{array}$ & Guerrero et al. (2009) & 4 & Independent \\
\hline Food Identity (FI) & $\begin{array}{l}\text { Hjalager \& Corigliano (2000); Robinson \& Clifford } \\
\text { (2012);Muhammad \& Chan (2011) }\end{array}$ & 15 & Dependent \\
\hline
\end{tabular}




\section{Data Analysis and Finding}

\subsection{Descriptive analysis of demographic background}

From the 898 public respondents, $59.4 \%$ of them were female, and $40.6 \%$ were male. Based on ethnicity, a majority were Malay (78.1\%); followed by Chinese (11.5\%); Indian (8.8\%) and the lowest percentage were Others (1.7\%) groups, mainly comprising of Bumiputera ethnics: Sabah and Sarawak. In terms of age group, more than half of the respondents were between $30-35$ years $(62.4 \%)$; $36-40$ years (18\%); $41-50$ years $(6 \%) ; 46-50$ years $(6.6 \%)$ and lastly > 51 years and above account for $7 \%$ of the overall respondents. In profession, most of respondents are in the private sector (41.5\%); government sector (33\%); professional background (9.7\%) (i.e. entrepreneur); students (9.6\%) and others consist of housewife, and pensioner with $6.2 \%$. As for educational background, a majority were Diploma holders (40.3\%); followed by Degree holders (24.9\%); Master's degree holder (12.9\%); Sijil Pelajaran Malaysia at 14.4\%; Sijil Rendah Pelajaran or Penilaian Menengah Rendahwith 2.4\%; others (i.e. MCE, STPM, primary school, certificate holders) at $1.1 \%$ and the lowest were Ujian Pencapaian Sekolah Rendahat $0.4 \%$.

\subsection{Summary of reflective measurement model and reliability}

Assessment of reflective measurement models includes four criteria: 1) composite reliability (CR) to evaluate internal consistency; 2) individual indicator reliability; 3) average variance extracted (AVE) to evaluate convergent validity and 4) FornellLarcker criterion and cross- loadings are used to assess discriminant validity (DV). The first criterion to be evaluated is typically Internal Consistency Reliability. The traditional criterion for internal consistency is Cronbach's alpha, which provides an estimate or the reliability based on the inter-correlations of the observed indicator variables. Cronbach's alpha assumes that all indicators are equally reliable (i.e., all the indicators have equal outer loadings on the construct). However, PLS-SEM prioritizes the indicators, according to their individual reliability. Moreover, Cronbach's alpha is sensitive to the number of items in the scale and tends to underestimate the internal consistency reliability. As such, it may be used as a conservative measure of internal consistency reliability. Due to the limitation of Cronbach alpha's in the population, it is more appropriate to apply a different measure of internal consistency reliability, which is referred to as CR. This type of reliability takes into account the different outer loadings of the indicator variables. The $C R$ varies between 0 and 1 , with higher values indicating higher levels of reliability. It is interpreted in the same way as Cronbach's alpha. Specifically, CR values of 0.60 to 0.70 are acceptable in exploratory research, while, in more advanced stages of research, values between 0.70 and 0.90 can be regarded as satisfactory. Table 2 shows the results of reliability test, which demonstrated that the CR values 0.60 to 0.80 exceed the range of the recommended values of 0.60 and 0.70 as suggested by Hair Jr, Hult, Ringle, and Sarstedt (2014) therefore it can be concluded that the measurements are reliable.

Individual indicator reliability is shown by high outer loadings, which are in the same group of convergent validity. All indicators' outer loading should be statistically significant. The common rule of thumb is outer loadings should be 0.708 since that value is squared which is equal to 0.50 . It is also noted that 0.70 is considered close enough to 0.708 to be acceptable. Hair Jr et al. (2014)further explained that the outer loading between 0.40 and 0.70 should be considered for removal from the scale only when deleting the indicator, which leads to an increase in the CR or the AVE and the removal will not affect content validity. However, if the item is below 0.40 it should be eliminated(Hair, Ringle, \& Sarstedt, 2011). Results showing an overall CR value of 0.80 to 0.95 (Table 2 ) justify the well above the minimum requirement.

Convergent validity is the degree to which multiple items measuring the same concept are in agreement. According to Hair et al. (2014) the common measure to establish convergent validity on the construct level is AVE. An AVE value of 0.50 or higher indicates that on average the constructs explain more than half of the variance of its indicators. Conversely, an AVE of less than 0.50 indicates that on average more error remains in the items than the variance explained by the construct. Overall results showed all the AVE value well above 0.50 (Table2). Hence, the measurement model of this study demonstrated adequate convergent validity.

Table 2. Measurement models (Reflective Constructs)

\begin{tabular}{cccccc}
\hline Latent & Indicators & Outer & Composite & Average & Discriminant \\
Variable & $($ Item $)$ & Loadings & $\begin{array}{c}\text { Reliabilities } \\
(\mathrm{CR})\end{array}$ & $\begin{array}{c}\text { Variance } \\
\text { Extracted }\end{array}$ & Validity \\
& & & & \\
\hline
\end{tabular}


Md. Ramli, A., et.al. / 6 ${ }^{\text {th }}$ AicE-Bs2015Barcelona, Spain, 30 Aug.- 04 Sep. 2015 / E-BPJ, Maiden Issue, 1(1) June 2016 (pp.207-216)

\begin{tabular}{|c|c|c|c|c|c|}
\hline (Construct) & & & & (AVE) & (DV) \\
\hline Historical & HV1 & 0.726 & 0.849 & 0.585 & Yes \\
\hline \multirow[t]{3}{*}{ Value } & HV3 & 0.788 & & & \\
\hline & HV4 & 0.771 & & & \\
\hline & HV5 & 0.773 & & & \\
\hline Traditional & TV1 & 0.776 & 0.896 & 0.518 & Yes \\
\hline \multirow[t]{7}{*}{ Originality } & TV2 & 0.747 & & & \\
\hline & TV3 & 0.670 & & & \\
\hline & TV5 & 0.722 & & & \\
\hline & OR2 & 0.679 & & & \\
\hline & OR3 & 0.726 & & & \\
\hline & OR4 & 0.682 & & & \\
\hline & OR5 & 0.751 & & & \\
\hline Staple & SI1 & 0.733 & 0.861 & 0.554 & Yes \\
\hline \multirow[t]{4}{*}{ Ingredients } & SI2 & 0.721 & & & \\
\hline & $\mathrm{SI} 3$ & 0.785 & & & \\
\hline & SI4 & 0.705 & & & \\
\hline & Sl5 & 0.773 & & & \\
\hline Flavour & FV1 & 0.841 & 0.867 & 0.685 & Yes \\
\hline \multirow[t]{2}{*}{ Principle } & FV3 & 0.823 & & & \\
\hline & FV5 & 0.818 & & & \\
\hline Cooking & CM2 & 0.794 & 0.813 & 0.593 & Yes \\
\hline \multirow[t]{2}{*}{ Method } & CM3 & 0.757 & & & \\
\hline & CM4 & 0.758 & & & \\
\hline Food & FP2 & 0.815 & 0.825 & 0.611 & Yes \\
\hline \multirow[t]{2}{*}{ Presentation } & FP3 & 0.798 & & & \\
\hline & FP4 & 0.730 & & & \\
\hline Variety and & VC3 & 0.751 & 0.897 & 0.522 & Yes \\
\hline \multirow[t]{7}{*}{ Commonality } & VC4 & 0.677 & & & \\
\hline & VC5 & 0.754 & & & \\
\hline & CC1 & 0.746 & & & \\
\hline & $\mathrm{CC} 2$ & 0.761 & & & \\
\hline & CC4 & 0.720 & & & \\
\hline & $\mathrm{CC} 4$ & 0.683 & & & \\
\hline & $\mathrm{CC5}$ & 0.681 & & & \\
\hline Process and & PT2 & 0.843 & 0.840 & 0.639 & Yes \\
\hline \multirow[t]{2}{*}{ Technology } & PT3 & 0.691 & & & \\
\hline & PT4 & 0.853 & & & \\
\hline Food & IM1 & 0.753 & 0.945 & 0.535 & Yes \\
\hline \multirow[t]{4}{*}{ Identity } & IM2 & 0.725 & & & \\
\hline & IM3 & 0.689 & & & \\
\hline & IM4 & 0.728 & & & \\
\hline & IM5 & 0.750 & & & \\
\hline
\end{tabular}




\begin{tabular}{ll} 
IM6 & 0.727 \\
AT2 & 0.737 \\
AT3 & 0.736 \\
AT4 & 0.722 \\
AT5 & 0.715 \\
ST1 & 0.757 \\
ST2 & 0.723 \\
ST3 & 0.744 \\
ST4 & 0.749 \\
ST5 & 0.711 \\
\hline
\end{tabular}

Lastly, the discriminant validity (DV) examines whether items load more strongly on their constructs in the model. The square root of average variance shared between each construct and its measures should be greater than the variance shared between the construct and another construct (Hair et al., 2014). Overall results support that the squared correlations for each construct are less than the square root of the average variance extracted by the indicators. Thus, this study demonstrated adequate discriminant validity as shown in Table 2 and 3. The results summarize the reflective measurement model assessment for DFH and FImeasures' reliability and validity of the model and have been fulfilled. With that, the model of DFH and FI can now advance to determine the relationship between the DFH and FI determinants using path coefficient analysis.

Table 3.Summary discriminant validity

\begin{tabular}{cccccccccc}
\hline & CM & FI & FP & FV & HV & PT & SI & TVOr & VcCc \\
\hline CM & 0.770 & & & & & & & & \\
FI & 0.524 & 0.731 & & & & & & & \\
FP & 0.679 & 0.555 & 0.782 & & & & & & \\
FV & 0.609 & 0.568 & 0.605 & 0.827 & & & & & \\
HV & 0.541 & 0.439 & 0.545 & 0.573 & 0.765 & & & & \\
PT & 0.490 & 0.599 & 0.445 & 0.509 & 0.453 & 0.799 & & & \\
SI & 0.660 & 0.531 & 0.596 & 0.707 & 0.577 & 0.533 & 0.744 & & \\
TVOr & 0.532 & 0.469 & 0.522 & 0.567 & 0.724 & 0.445 & 0.522 & 0.720 & \\
VcCc & 0.559 & 0.666 & 0.560 & 0.584 & 0.556 & 0.787 & 0.584 & 0.510 & 0.722 \\
\hline
\end{tabular}

\subsection{Relationship between DFH and FI}

A preliminary assessment of the structural model (inner model) and theoretical framework was conducted by determining the R-square (R2) measure of the endogenous constructs and the path coefficients (Chin, 2010; Hair et al., 2011). In doing so, the path coefficients must be significant, and R2is highly dependent on the research area. Chin (1998) suggested that measures of $0.67,0.33$, and 0.19 for R2 considered substantial, moderate, and weak, respectively. The R2 values of the endogenous constructs in this study were 0.529 , which showed there is a moderate relationship between DFH and FI. Fig. 1. present the results of the structural model for the relationships between the constructs to testing the direct effects. 


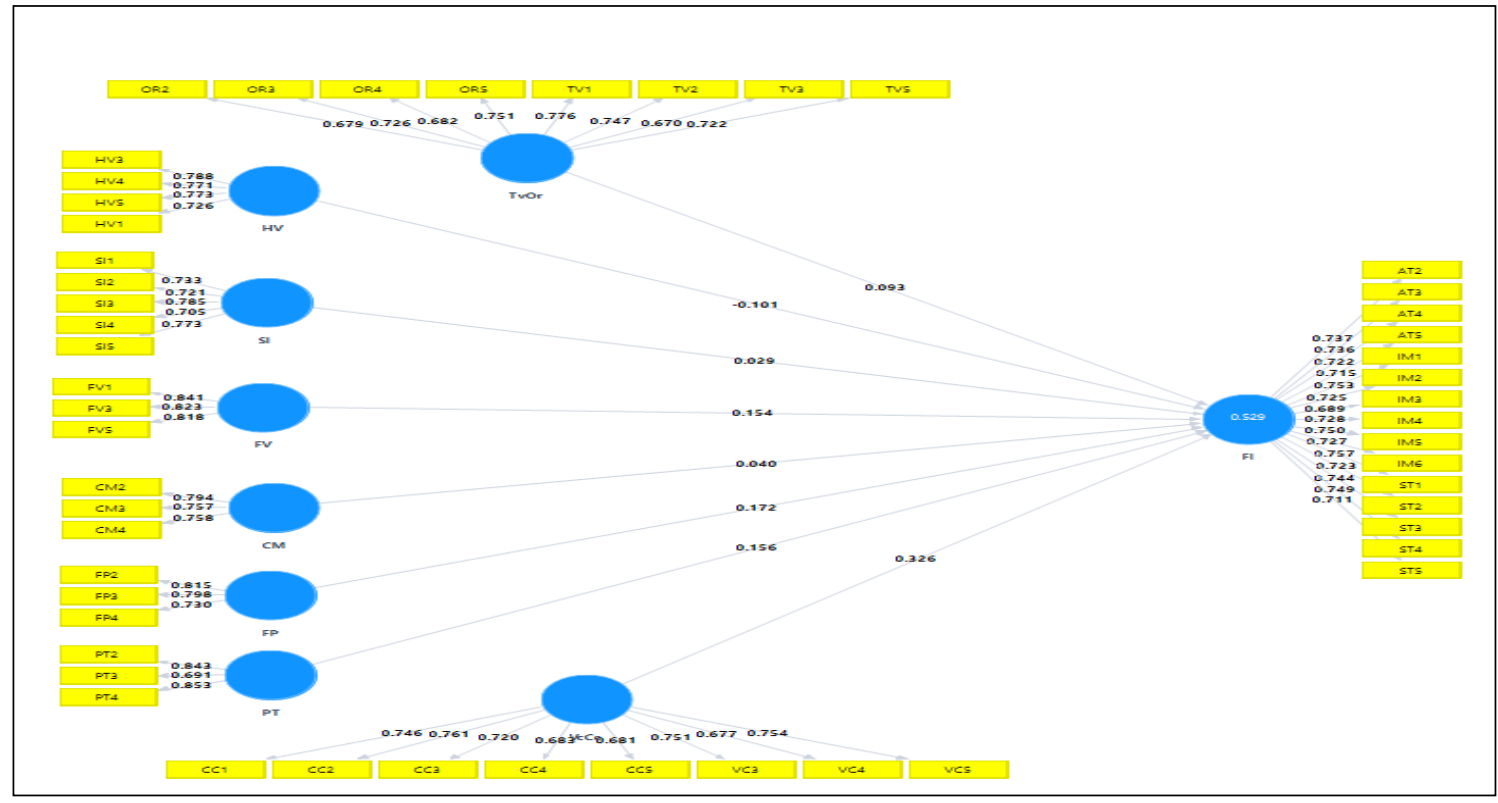

Fig. 1. Results of the path analysis (R2)

\subsection{Discussion}

These studies examine the conceptual framework of determinant food heritage (DFH) and food identity (FI) and observe the relationship between both factors. The studies have established the reliability and validity of the determinants. Results also showed there is a moderate relationship between the DFH and FI showing there is a relation between the two determinants. AsKeillor and Hult (1999)state that the belief structure, cultural homogeneity; ethnocentrism and national heritage are the elements of heritage. The national heritage is related to the historical figures and events in history whose components reflect the given culture's sense of their unique history this can be related in the context of nation identity. Meanwhile, Park (2010) recognizes the importance of the socio-psychological dimensions such as perception, emotional attachment of an individual toward heritage highlighting the interconnected with nation identity. While,Chhabra (2005)views authenticity as part of heritage through products and merchandises represent as nation identity. The DFH and FI conceptual model can be a useful tool in selecting FH in meeting the criteria in section 67 (2) in the Declaration of National Heritage, Act 645, 2005 before endorsing them to become National Food Heritage. DFH criteria's such as SI, FV, CM, and FP have been identified by several researchers as food characteristic elements which consist of four elements: basic food, distinct preparing method, flavor principle and table set of manner (Belasco, 2008; Meiselman \& MacFie, 1996; Rozin, 2006).As how important to have a tool or mechanism for FH, Tibere and Aloysius (2013) stated that it is pivotal for the government to consider building a supportive policy and planning framework conducive to the Malaysian food heritage development. In this context, the framework of determinants the DFH and FI have been established.

\section{Conclusion and Limitation}

The results of this study are subject to certain limitations that need to be considered. In the study, the first step is to understand the DFH and FI elements using past literature and the need to testing the validity and reliability of the DFH and FI constructs continually as the model of DFH is still not fully developed particularly in Malaysia. Determining and understanding the determinants of food heritages without a doubt will directly benefit many parties, for example, government authority such as Ministry of Tourism and Culture, state government agencies and non-governmental organizations (NGO). Determinants framework that have been obtained from this study, besides creating the foundation and practical guidelines, also aid in developing standard mechanisms or standardized tools for certification and endorsement of food heritage that can be used by all parties. It will also help the relevant authorities' in creating preservation of food culture and documentation for future reference. 
Several limitations have been recognized in this study. One of them is that the sample size for each ethnic is not an equal ratio, which means that the findings may only be generalized to the entire population in Klang Valley area. Therefore, interpretation and generalization of the findings DFH and FI must be done with caution. It is suggested for future studies to examine public respondents from each state to represent the Malaysian context and to use a different sampling method that may complement this study. The paper suggests that future research, specifically in the field of sociology and tourism, studies the social interaction pattern in the local food and culinary culture, which would be a beneficial contribution towards a more comprehensive sustainable tourism development for the country.

\section{Acknowledgements}

This paper was funded by Universiti Teknologi MARA under the Fundamental Research Grant Scheme (FRGS) grant, 600 RMI/FRGS 5/3 (125/2013).

\section{References}

Alba, R., Portes, A., Kasinitz, P., Fonari, N., Anderson, E., \& Glazer, N. (2000). Beyond the Melting Pot 35 Years Later : On the Relevance of a Sociological classic for the Immigration Metropolis of Today. The International Migration Review, 34(1), 243.

Avieli, N. (2005). Vietnamese New Year Rice Cakes: Iconic Festive Dishes and Contested National Identity. Ethnology, 44(2), 167-187.

Belasco, W. (2008). Food: The key concepts. Oxford: Berg Publishers.

Bennett, C. (2001). Genres of Research in Multicultural Education. Review of Educational Research, 71(2), 171-217.

Bernama. (2012, 10 Mei 2012). 154 Butiran Diisytihar Sebagai Warisan Kebangsaan, Bernama. Retrieved from www.bernama.com

Burgess, C. (2004). Maintaining Identities, Discourses of Homogeneity in a Rapidly Globalizing Japan. Electronic Journal of Contemporary Japanese Studies, (1).

Chhabra, D. (2005). Defining Authenticity and Its Determinants: Toward an Authenticity Flow Model. Journal of Travel Research, 44(1), 64-73.

Chin, W. W. (1998). The partial least squares approach to structural equation modeling. Modern methods for business research, 295(2), 295-336.

Chin, W. W. (2010). How to write up and report PLS analyses Handbook of partial least squares (pp. 655-690): Springer

Chong, J. W. (2009). The Indonesia-Malaysia Dispute Over Shared Cultural Icons And Heritage. ILSP Law Journal, 177-186.

Chong, J. W. (2012). " Mine, Yours or Ours?": The Indonesia-Malaysia Disputes over Shared Cultural Heritage. SOJOURN: Journal of Social Issues in Southeast Asia, 27(1), 1-53.

Cleveland, M., Laroche, M., Pons, F., \& Kastoun, R. (2009). Acculturation and consumption: Textures of cultural adaptation. International Journal of Intercultural Relations, 33(3), 196-212.

Demo, D. H. (1992). The Self-Concept Over Time: Research Issues and Directions. Annual Review of Sociology, 18, 303-326.

DeSoucey, M. (2010). Gastronationalism: Food Traditions and Authenticity Politics in the European Union. American Sociological Review, 75(3), 432-455

Esser, H. (2003). Does the New Immigration Require a New Theory of Intergenerational Integration? Universitat Mannheim. Retrieved from http://www.mzes.unimannheim.de.

Farahani, B. M., Abooali, G., \& Mohamed, B. (2012). George Town World Heritage Site: What We Have and What We Sell? Asian Culture and History, 4(2).

Goh, Y.-N. (2015). Investigating Revisit Intentions for the Boutique Hotels of Penang-A UNESCO World Heritage Site. Asian Social Science, 11 (4), p126.

Guerrero, L., Guardia, M. D., Xicola, J., Verbeke, W., Vanhonacker, F., Zakowska-Biemans, S., . . Hersleth, M. (2009). Consumer-driven definition of traditional food products and innovation in traditional foods. A qualitative cross-cultural study. Appetite, 52, 345-354.

Hair, J. F., Money, A. H., Samouel, P., \& Page, M. (2007). Research Methods for Business. USA: John Wiley \& Sons Itd.

Hair, J. F., Ringle, C. M., \& Sarstedt, M. (2011). PLS-SEM: Indeed a silver bullet. Journal of Marketing Theory and Practice, 19(2), $139-152$.

Hair Jr, J. F., Hult, G. T. M., Ringle, C., \& Sarstedt, M. (2014). A primer on partial least squares structural equation modeling (PLS-SEM): Sage Publications.

Halim, M. A. S. A., \& Mat, A. C. (2010). The contribution of heritage product toward Malaysian Tourism Industry: A case of eastern coastal of Malaysia. International Journal of Human Sciences, 7(2), 346-357.

Hjalager, A.-M., \& Corigliano, M. A. (2000). Food for tourists-determinants of an image. International Journal of Tourism Research, 2(4), $281-293$.

Horng, J.-S., \& Tsai, C.-T. (2010). Government websites for promoting East Asian culinary tourism: A crosss-national analysis. Tourism Management, 31(1), 7485.

Howard, J. A. (2000). Social Psychology of Identities. Annual Review of Sociology, 26, 367-393.

Hui-Tun, C. (2009). The Rise of Culinary Tourism and Its Transformation of Food Cultures: The National Cuisine of Taiwan. Copenhagen Journal of Asian Studies, 27(2), 84-108.

Hui-tun, C. (2010). Fabricating Authentic National Cuisine Identity and Culinary Practice in Taiwan. (Ph.D. 3458093), New School University, United States -New York. Retrieved from http://search.proquest.com.ProQuest Dissertations \& Theses (PQDT).

Ishak, N., Zahari, M. S. M., Sharif, M. S. M., \& Muhammad, R. (2012). Acculturation, Foodways and Malaysian Food Identity. Paper presented at the Current Issues in Hospitality and Tourism and Innovations, Kuala Lumpur.

Keillor, B. D., \& Hult, G. T. M. (1999). A five-country study of national identity: implications for international marketing research and practice. International Marketing Review, 16(1), 65-84. 
Kwik, J. C. (2008). Traditional Food Knowledge: Renewing Culture and Restoring Health. (Master ), University of Waterloo, Published Heritage Branch. Library and Archives Canada database.

Lim, Y. (2012). KL central cultural makeover, The Star online. Retrieved from http://thestar.com.my.

Lin, Y.-C., Pearson, T. E., \& Cai, L. A. (2011). Food as a form of destination identity: A tourism destination brand perspective. Tourism and Hospitality Research, 11(1), 30-48.

Malaysia. (2006). National Heritage Act 2005 (Act 645) Malaysia: International Law Book Services 2006.

Matta, R. (2013). Valuing Native Eating: The Modern Roots of Peruvian Food Heritage. Anthropology of food, S8. http://aof.revues.org/7361

McDonald, H. (2011). Understanding the antecedents to public interest and engagement with heritage. European Journal of Marketing, 45(5), $780-804$.

Md Nor, N., Sharif, M. S. M., Zahari, M. S. M., Salleh, H. M., Isha, N., \& Muhammad, R. (2012). The Transmission Modes of Malay Traditional Food Knowledge within Generations. Procedia - Social and Behavioral Sciences, 50(0), 79-88.

Meiselman, H. L., \& MacFie, H. J. (1996). Food choice acceptance and consumption. London: Blackie Academic \& Professional.

Mohammad, T., \& Chan, J. K. L. (2011). Authenticity Representation of Malay Kelantan Ethnic Cuisine. Paper presented at the The 2nd International Research Symposium in Service Management, Yogyakarta, INDONESIA.

Negara, J. W. (2012). Perisytiharan Warisan Kebangsaan. In J. W. Negara (Ed.), Kementerian Penerangan Komunikasi dan Kebudayaan (pp. 19). Malaysia: Jabatan Warisan Negara.

Negara, J. W. (2015). Jabatan Warisan Negara. Retrieved 3 Julai 2015, 2015, from http://www.heritage.gov.my

Nor, R. H. (2006). Taklimat Akta 645 Warisan Kebangsaan 2005 (National Heritage Act 2005) Akta 645. Paper presented at the National Heritage Act 2005, Cititel Mid Valley, Kuala Lumpur.

Park, H. Y. (2010). Heritage tourism Emotional journeys into nationhood. Annals of Tourism Research, 37(1), 116-135.

Phinney, J. S. (1990). Ethnic identity in adolescents and adults: review of research. Psychological Bulletin, 108(3), 499.

Ramli, A., \& Zahari, M. (2014). Determinants of food heritage in Malaysia context. Theory and Practice in Hospitality and Tourism Research, 477.

Ramli, A. M., Zahari, M. S. M., Halim, N. A., \& Aris, M. H. M. (2015). Knowledge and Awareness on Food Heritage in Klang Valley, Malaysia. Paper presented at the AicQoL2015 Jakarta, "Quality of Life in the Build \& Natural Environment", AMER International Conference on Quality of Life, Jakarta, Indonesia.

Ramli, A. M., Zahari, M. S. M., \& Talib, S. A. (2014). Identification of Food Heritage: Food Identity Analysis on Demographic Background. Paper presented at the National Research \& Innovation Conference for the Graduate Students in Social Sciences 2014, Corus Paradise Resort, Port Dickson, Negeri Sembilan.

Ratnasingam, M. (2010). National Identity: A Subset of Social Identity? In M. K. David, J. McLellan, N. Y. Meng, L. M. Li \& W. Y. M. Tien (Eds.), Ethnic Relations and Nation Building: The Way Forward (pp. 3-34). Petaling Jaya, Selangor, Malaysia: Strategic Information and Research Development Center

Ringle, C. M., Wende, Sven, \& Becker, J.-M. (2015). SmartPLS 3. Retrieved from http://www.smartpls.com

Robinson, R. N., \& Clifford, C. (2012). Authenticity and festival foodservice experiences. Annals of Tourism Research, 39(2), 571-600.

Rozin, P. (2006). The integration of biological, social, cultural and psychological influences on food choice. In R. Shepherd \& M. Raats (Eds.), The psychology of food choice (pp. 19-39). UK: CAB International

Salkind, N. J. (2003). Exploring Research United States of America: Prentice Hall.

Shane, S. (1994). The Effect of National Culture on the Choice between Licensing and Direct Foreign Investment. Strategic Management Journal, 15(8), 627642.

Shariff, N. M., Mokhtar, K., \& Zakaria, Z. (2008). Issues in the Preservation of Traditional Cuisines: A Case Study in Northern Malaysia. International Journal of the Humanities, 6(6), 101-106.

Shariff, N. M., \& Zakaria, Z. (2011). Digital Mapping of Intangible Cultural Heritage: The Case of Traditional Foods. International Journal of the Humanities, 8(11), 69-74.

Tibere, L., \& Aloysius, M. (2013). Malaysia as a Food-Haven Destination: The Vision and its Sustainability. Asia-Pacific Journal of Innovation in Hospitality and Tourism, 2(1), 37-51.

UNESCO. (2008). World Heritage Information Kit. France: UNESCO World Heritage Center Retrieved from http://whc.unesco.org.

Utusan. (2010, 25 April 2010). Hayati Warisanmenerusimakanan, minuman, Newspaper, Utusan Malaysia Online.

Valley, G. K. L. K. (2014). Greater KL/KV comprises 10 local authorities. Retrieved 28 Dec 2014, 2014, from http://app.kwpkb.gov.my

Vanhonacker, F., Verbeke, W., Guerrero, L., Claret, A., Contel, M., Scalvedi, L., .. Hersleth, M. (2010). How European consumers define the concept of traditional food: evidence from a survey in six countries. Agribusiness, 26(4), 453-476. doi: 10.1002/agr.20241

Vecco, M. (2010). A definition of cultural heritage: From the tangible to the intangible. Journal of Cultural Heritage, 11(3), 321-324.

Vertovec, S. (1999). Minority associations, networks and public policies: Re - assessing relationships. Journal of Ethnic and Migration Studies, 25(1), 21-42. doi: 10.1080/1369183x.1999.9976670

Wahid, N. A., Mohamed, B., \& Sirat, M. (2009). Heritage food tourism: bahulu attracts? Paper presented at the Proceedings of 2nd National Symposium on Tourism Research, Universiti Sains Malaysia, Penang, Malaysia 18 July 2009. Theories and Applications.

Wo, C. T. (2009). Dish branding,thestar. Retrieved from http://thestar.com.my.

Yusoff, Y. M., Dollah, H., Kechot, A. S., \& Din, M. A. O. (2010). Pembangunan Warisan di Malaysia: tinjauanumumtentangdasar. Jurnal Melayu, 5, $277-283$. 